NOTICE: this is the author's version of a work that was accepted for publication in Marine Policy. Changes resulting from the publishing process, such as peer review, editing, corrections, structural formatting, and other quality control mechanisms may not be reflected in this document. Changes may have been made to this work since it was submitted for publication. A definitive version was subsequently published in Marine Policy, Vol. 44 (2014).

DOI: 10.1016/j.marpol.2013.08.020 
Hobbs J-P.A. (2014) A glaring omission in Australia's marine conservation planning. Marine Policy 44:149-151.

\section{A glaring omission in Australia's marine conservation planning}

Jean-Paul Adrian Hobbs

The Oceans Institute and School of Plant Biology, The University of Western Australia, Crawley, 6009, Australia

Phone: +61864884648

Fax: +61864887278

E-mail: jean-paul.hobbs@uwa.edu.au 


\section{A glaring omission in Australia's marine conservation planning}

The recent paper by Barr and Possingham [1] demonstrates that Australia's National Representative System of Marine Protected Areas (NRSMPA) is clearly not representative. The authors propose reasons for why the Australian Government has decided on a non-representative and non-quantitative approach to management plans for conserving Australia's marine biodiversity. The authors identify that the Christmas Island Province and the Cocos (Keeling) Islands Province have the least $(<1 \%)$ protection of the 85 marine bioregions (Figure 6, [1]), but do not discuss why these provinces have been neglected by the Australian Government.

The two provinces are located in the tropical eastern Indian Ocean and collectively this area is referred to as the Sunda Province $[2,3]$. The reason why the Christmas and Cocos provinces have the least protection is because they have been omitted from the NRSMPA planning process (compare Figure 1 and 2 in [1]). This begs the question as to why these two provinces are not part of the Australian Government's management plans for conserving marine biodiversity.

The marine bioregions and provinces identified in the NRSMPA planning process were determined from data on species richness and composition of shallow water fishes ( 0 to $200 \mathrm{~m}$ depth)[2,3]. The shallow water fish communities of Christmas and Cocos Islands are species rich compared to the rest of Australia (>800 species in total, [4-6], Hobbs et al. unpublished data) and have a globally unique composition because they lie on the Indo-Pacific biogeographic border [7]. This includes the greatest number of hybrid reef fishes in the world [8] and more than 50 fish species not found anywhere else in Australian waters $[5,6]$. These islands have numerous endemic fishes [5,9], with Christmas Island ranked seventh in the world for the number of endemic coral reef fishes per area of habitat [10]. The Cocos Islands has some the world's highest densities of vulnerable fishes $[11,12]$, while Christmas Island is one of only two Australian locations that have known whale shark aggregations [13]. Therefore, based on the metric (fishes) used to define marine bioregions, the Christmas and Cocos provinces should have been among the first protected by the NRSMPA.

Although the marine environment of the Christmas and Cocos provinces has received little research, it is still evident that its unique and rich marine biodiversity is not limited to fishes. For example, limited surveys have identified more than 600 mollusc species and over 200 crustacean species from shallow waters $(<20 \mathrm{~m})$ at the Cocos Islands $[14,15)$. Christmas Island has an extraordinary unique community of crabs, with a high proportion of endemic species that are continually being discovered [16]. Furthermore, the island has the greatest diversity of land crabs in the world and these crabs are the keystone species of the terrestrial ecosystem [16]. This system is entirely reliant on the survival of land crab offspring during the marine larval phase. The anchialine fauna of Christmas Island is also of international significance [17]. Both Christmas and Cocos are internationally renowned as some of the most important seabird rookeries in the Indian Ocean, including several endemic species. The unusual characteristics and formation of the abyssal plain and 
seamounts in the deep waters ( $>4000 \mathrm{~m}$ ) surrounding the islands are not present in other bioregions, and are likely to support unique and diverse biological communities [18]. The Cocos Islands are considered Australia's only true coral atoll [19] and no other Australian island has the karst network of underwater caves that are present at Christmas Island. By any metric, the Cocos and Christmas provinces would be among the most unique marine bioregions in Australia and throughout the Indo-Pacific and their protection should be a NRSMPA priority.

Greater protection of the unique marine biodiversity of the Christmas and Cocos provinces is also warranted given the lack of existing protection $(<1 \%)$ and the range of impacts that are threatening this biodiversity. Coral bleaching, disease and crown-of-thorns starfish have significantly affected corals reefs in the Christmas and Cocos provinces [20,21] and this habitat loss has resulted in the local extinction of at least one fish species [6]. At Christmas Island, more than 63 marine species are at risk and listed under the Environmental Protection and Biodiversity Conservation (EPBC) Act [22] because they require additional protective management. Despite numerous listed species, there is no protection from impacts such as the 2012 grounding of the MV Tycoon, where a poor management response (due to a lack of planning, action and resources) resulted in hundreds of tonnes of oil, diesel and phosphate being spilt onto coral reefs for months. Furthermore, continued phosphate-rich sedimentation from local mining operations goes unregulated. At the Cocos Islands, there are limited fishing regulations and no active compliance and thus overfishing has pushed several species (including those listed by the IUCN as "Vulnerable") to the brink of local extinction (e.g. coral trout and giant clam: [11]). In addition, a history of mass die-off events has resulted in mortality to millions of marine organisms $[23,24]$. Furthermore, the isolation of Christmas and Cocos Islands reduces resilience because populations with limited connectivity will be slower to recover from impacts, compared to mainland bioregions [25].

An increasing threat to the marine biodiversity of the Cocos and Christmas provinces is the illegal arrival of foreign boats. In the last 4 years more than 500 vessels carrying asylum seekers have entered Australian waters without permission with a large proportion arriving off Christmas Island and to a lesser extent the Cocos Islands. These vessels are brought in close to shore, are often tied up to moorings, and at least five have run aground on Christmas or Cocos. The unregulated entry of these decrepit vessels poses a high risk of introducing marine pests and diseases. Given that introduced species and diseases have devastated terrestrial biodiversity at Christmas Island, causing numerous extinctions [17], the lack of protection against these threats poses a significant risk to the region's unique marine biodiversity.

The multitude of governance arrangements in the Christmas and Cocos provinces may make it difficult to plan and implement marine reserve protection, however it increases the risk of biodiversity loss. Following an investigation into the extinction crisis occurring in the terrestrial environment at Christmas Island, a government-assigned expert working group identified that both the level and complexity of governance arrangements was a major 
hindrance to management actions aimed at conserving biodiversity [17]. The expert group made a high priority recommendation that environmental governance be changed to a single authority. The Australian Government rejected this recommendation. Successful management of a marine protected area across multiple governmental jurisdictions is necessary to avoid biodiversity loss, and is possible, as exemplified by the Great Barrier Reef [1].

If protecting the unique marine biodiversity of the Christmas and Cocos provinces is not a priority then biodiversity loss will occur due to conflicting priorities. For example, the arrival of asylum seekers and their confinement at the Christmas Island Immigration Detention Centre is a very contentious issue that has received much media attention and featured heavily in recent federal elections. To build and operate the Detention Centre the Australian Government has circumvented the EPBC Act thereby avoiding its own legal environmental obligations that were established to protect biodiversity. This has had numerous negative impacts on the Island's biodiversity, including impacts to many vulnerable species that are protected under the EPBC Act $[16,22]$. Therefore, failing to include the Christmas and Cocos provinces in the NRSMPA places the region's unique biodiversity at risk from the government's other priorities.

The primary goal of the NRSMPA was to develop a "comprehensive, adequate and representative system of MPAs" that will protect Australia's marine biodiversity. However, the Christmas and Cocos provinces represent a glaring contradiction to this policy in that they are among the most unique and threatened marine bioregions in Australia, yet receive no protection from the NRSMPA. The lack of protection appears to be because of difficulties with existing governance arrangements and/or other political priorities. Both of these reasons have already caused population declines and extinctions in the terrestrial environment of this bioregion [17]. The exclusion of the Christmas and Cocos provinces from the NRSMPA represents a clear failure by the Australian Government to conserve marine biodiversity in this bioregion. The Australian Government must urgently reconsider the lack of protection within the Christmas and Cocos provinces otherwise marine biodiversity in this region may be irrevocably impacted. The evidence presented here concurs with Barr and Possingham [1] that the NRSMPA is not an example of a representative system, does not provide an adequate level of protection for the biodiversity in each marine bioregion, and will tarnish the Australian Government's international reputation as a world-leader in marine biodiversity protection.

\section{References}

[1] Barr LM, Possingham HP. Are outcomes matching policy commitments in Australian conservation planning? Marine Policy 2013;42:39.

[2] IMCRA Technical Group. Interim marine and coastal regionalisation for Australia: an ecosystem-based classification for marine and coastal environments. Canberra: Environment Australia, Commonwealth Department of the Environment; 1997 Version 3.2.

[3] Commonwealth of Australia. A Guide to the Integrated Marine and Coastal Regionalisation of Australia. Canberra: Australian Government Department of the Environment and Heritage; 2006 Version 4.0. 
[4] Allen GR, Smith-Vaniz WF. Fishes of Cocos (Keeling) Islands. Atoll Research Bulletin 1994;412:1.

[5] Allen GR, Steene R, Orchard M. Fishes of Christmas Island. 2nd ed., Christmas Island: Christmas Island Natural History Association; 2007.

[6] Hobbs J-PA, Ayling AM, Choat JH, Gilligan JJ, McDonald CA, Neilson J, et al. New records of marine fishes illustrate the biogeographic importance of Christmas Island, Indian Ocean. Zootaxa 2010;2422:63.

[7] Hobbs J-PA, Jones GP, Munday PL, Connolly SR, Srinivasan M. Biogeography and the structure of coral reef fish communities on isolated islands. Journal of Biogeography 2012;39:130.

[8] Hobbs J-PA, Frisch AJ, Allen GR, van Herwerden L. Marine hybrid hotspot at Indo-Pacific biogeographic border. Biology Letters 2009;5:258.

[9] Hobbs J-PA, Jones GP, Munday PL. Rarity and extinction risk in coral reef angelfishes on isolated islands: interrelationships among abundance, geographic range size and specialization. Coral Reefs 2010;29:1.

[10] Allen GR. Conservation hotspots of biodiversity and endemism for IndoPacific coral reef fishes. Aquatic Conservation: Marine and Freshwater Ecosystems 2008;18:541.

[11] Hender J, McDonald CA, Gilligan JJ. Baseline surveys of the marine environments and stock size estimates of marine resources of the south Cocos (Keeling) Atoll (0-15m), eastern Indian Ocean. Unpublished report to the Fisheries Resources Research Fund, 2001.

[12] Robbins WD, Hisano M, Connolly SR, Choat JH. Ongoing collapse of coral reef shark populations. Current Biology 2006;16:2314.

[13] Hobbs J-PA, Frisch AJ, Hamanaka T, McDonald CA, Gilligan JJ, Neilson J. Seasonal aggregation of juvenile whale sharks (Rhincodon typus) at Christmas Island, Indian Ocean. Coral Reefs 2009;28:577.

[14] Wells FE. Marine molluscs of the Cocos (Keeling) Islands. Atoll Research Bulletin 1994;410:1.

[15] Morgan GJ. Decapod Crustaceans of the Cocos (Keeling) Islands. Atoll Research Bulletin 1994;414:1.

[16]Orchard M. Crabs of Christmas Island. Christmas Island: Christmas Island Natural History Association; 2012.

[17] Beeton B, Burbidge A, Grigg G, Harrison P, How R, et al. Final Report Christmas Island Expert Working Group to Minister for the Environment, Water, Heritage and the Arts. Unpublished Report, Christmas Island National Park, 2010.

[18] Brewer DT, Potter A, Skewes TD, Lyne V, Andersen J, et al. Conservation values in Commonwealth waters of the Christmas and Cocos (Keeling) Islands remote Australian Territories. CSIRO Cleveland: Report to Department of Environment, Water, Heritage and the Arts, 2009.

[19] Australian State of the Environment Committee. Coasts and Oceans, Australia State of the Environment Report 2001 (Theme Report). CSIRO Publishing on behalf of the Department of the Environment and Heritage, 2001. [20] Colin PL. The reefs of Cocos-Keeling Atoll, eastern Indian Ocean. Proc. 3rd International Coral Reef Symposium. Florida: Univ. of Miami, 1977;63. [21] Hobbs J-PA, Frisch AJ. Coral disease in the Indian Ocean: prevalence and distribution of white syndrome on remote coral reefs. Diseases of Aquatic Organisms 2010;89:1. 
[22] James DJ. Christmas Island Biodiversity Monitoring Programme: Summary Report, December 2003 to April 2006. Parks Australia North Christmas Island Biodiversity Monitoring Programme: Report to Department of Finance \& Administration and Department of the Environment \& Water Resources, Canberra, 2007.

[23] Hobbs J-PA, McDonald CA. Increased temperature and decreased dissolved oxygen triggers fish kill at the Cocos (Keeling) Islands, Indian Ocean. Journal of Fish Biology 2010;77:1219.

[24] Hobbs J-PA, Macrae H. Unusual weather and trapped coral spawn leads to fish kill at a remote coral atoll. Coral Reefs 2012;31:961.

[25] Ayre DJ, Hughes TP. Climate change, genotypic diversity and gene flow in reef-building corals. Ecology Letters 2004;7:273. 